\title{
Precision geoinformatical system of the pear gene-collection orchard
}

\author{
Tamás, J. ${ }^{1}$, Nagy A. ${ }^{1}$, Fórián T. ${ }^{1}$, Nyéki J. ${ }^{2}$ Szabó, T. ${ }^{3}$ \& Szabó Z. ${ }^{2}$ \\ University of Debrecen, Centre of Agricultural Sciences and Engineering, Faculty of Agricultural and Food \\ Sciences and Environmental Management, H-4032 Debrecen, Böszörményi 138, Hungary \\ ${ }^{1}$ Institute of Water and Environmental Management, tamas@agr.unideb.hu \\ ${ }^{2}$ Institute of Horticulture,nyeki@agr.unideb.hu \\ ${ }^{3}$ Research and Extension Centre for Fruit Growing, H-4244 Úffehértó, Vadastag 2.
}

\begin{abstract}
Summary: The principle task of the sustainable development is the preservation of the genetic variety, which is similar challenge in the horticulture regarding the sublimation of fruit species. The breeders of the traditional fruit strains give stock to the sustenance diversity of the agro-environment on the species and landscape level. In 2009, hyperspectral images have been taken by AISA Dual sensors from the pear gene pool in Újfehértó, Hungary. The hyperspectral data cube (in the wavelength range of 400-2500 nm, with $1.5 \mathrm{~m}$ ground resolution) ensured possibility to make the spectral library of pear species. In the course of the simultaneously field work the spatial position and individual extent of all pear trees was defined to set up a detailed GIS data base. The water stress sensitivity of single species and the descriptive spectral curves were determined with common evaluation of the spectral and spatial data. Based on the unique methodology processing and the hyperspectral data base suitable strains can be chosen for agro-environment and let take adaptive stocks regarding climate change into the genetic grafting work. Furthermore we could determine and map the sparsely species in the region with the help of the hyperspectral data.
\end{abstract}

Key words: pear genetic collection, remote sensing, precision orchard management

\section{Introduction}

On the basis of the United Nations Earth Summit in Rio de Janeiro in 1992 the biodiversity conversation is the important task for every country. Even so numerous species is disappearing off the earth decreasing Earth's biodiversity (Láng, 2007). Plant and animal species collected by human genetic breeding works and selected over more hundred years are less emphasized contrary to wild species (Lockie and Carpenter, 2009).

There are numerous species of these, which can only be found in a certain landscape. These species mean irreparable genetic sources same as wild and rare species. There are innumerable genetically encoded qualities - eg. resistivity against the diseases and frost, drought tolerance, unique colour and taste, and storage tolerance, which lack partly or in gross from the commercial species. Because of the continually changing consumer demand, and environmental and landscape aspect the preservation of every pear species having special or useful quality is necessary.

The countries maintain this particular genetic property in the special plantations - gene pool. In Hungary these examination plantation can be found in 4 different production sites - Cegléd, Érd, Fertőd, Újfehértó, where 7833 trees are cultivated with professional technology and high cost. The items of the genetic collections are fully documented and the data are registered by international norm. The recorded data ensure the identification, central registration, suitable access to provide using for the national or international researchers, breeders and teachers. The greater part of data was in analogous form and the smaller part of it was in digital form until 2008. The most important cause of the establishment of the geoinformatical system was the dismembered database and the difficult management or actualizing.

The optimal climatic conditions for pear are generally cooler and humid, with at least $65 \%$ of relative air humidity. There is a lack of these conditions in Újfehérto at the $30-40 \%$ in a year. At the examined site, pear species with large biomass concerned as those species which had major tolerance against drier and unfavourable environmental conditions. These genetic properties could be very important in the frame of the potential climate change. Stress, caused by the relative water lack, evolves in a short term physiological process. The first symptoms of water stress are often not visually observed, although those have negative effect on the yield quantity and quality. The airborne hyperspectral remote sensing data eliminate these disadvantages, since it can provide detailed spectral data from the whole canopy.

The aim was to create a new GIS - Remote Sensing data system, which can be the basis of the later agro-ecological decision support system. 


\section{Materials and methods}

Our investigation was carried out in the area of Fruit growing Research and Consultant non-profit company, at Újfehértó (47 49'30" N; $21^{\circ} 40^{\prime} 27^{\prime}$ ' E). Our study area is located in Nyírség, north of Újfehértó city. The total cultivated area (fruit plantations and arable land) of the research company is approximately $3 \mathrm{~km}^{2}$. The area of the genetic orchard is 5 ha. The plantation began in 1982; pomaceous trees were planted such as apple, pear, quince, medlar. The area of the pear orchard is 2.74 ha, with 1660 possible spaces of pear trees. In the 5 ha plantation of genetic collection it can be found 673 apple, 480 pear, 57 quince and 28 naseberry species, variety and hybrid at present. According to the traditional cultivation methods the row pace is $8 \mathrm{~m}$ and the space between the trees is $2 \mathrm{~m}$.

We carried out field works to survey the species and tree parameters of pear genetic collection, such as height, and to draw map of plantation with the help of TRIMBLE JUNO PDA. Two map data collection software were used DigiTerra and ArcPad. In the course of the field works every stock place in the pear genetic collection were measured by DGPS methods, where the survey accuracy was RMS < $0.2 \mathrm{~m}$ after the TRIMBLE PATHFINDER compensating calculation in Geostation environment. The height and width of trees were defined with the help of Leica Distro 8 laser distance meter. On the basis of field works new digital soil and nutriment supply maps were created to evaluate agro-ecological environment. Height measurements and digital photos of the trees were also carried out during the survey. Digital photos were taken of the fruits as well, although earlier taken photos of genetically typical, ripe fruits were set to the database.

The spatial data were also completed by airborne hyperspectral data to supply special data examination. To prepare the hyperspectral flight we used a digital ortophoto, which was taken in 2007 with a ground resolution of $0.5 * 0.5 \mathrm{~m}$. Since the applied joint camera is less known in Europe and it can also be reached as an investigation delivery, the details of the measurement are described below. In this case the hyperspectral image with high spatial resolution was prepared by AISA DUAL system. In 2007, the first AISA DUAL airborne hyperspectral cam system were installed and operated in cooperation the University of Debrecen, AMTC, Department of Water and Environmental Management with the Mechanization Institute of Agricultural Ministry in Gödöllö. The two hyperspectral sensors are assembling in a house; therefore it is known
ASIA DUAL system (Milics et al. 2010). The hyperspectral image with high spatial resolution was taken by the pushbroom hyperspectral imagery sensor with the help of two OxTS RT 3003 antennas. Before the imagery boresight type calibration was performed (Holzwarth et al., 2005). The atmospherically correction was done on the basis of the direct radiation measured by FODIS sensor detecting the changing of the radiation above the sensor. We modified the effects from the movements of the airplane with the navigation values, which is necessary to define the FODIS ratio.

The parameters of the hyperspectral image:

- Wavelength: 400-2450 nm (EAGLE: 400-970 nm and HAWK: 970-2450 nm);

- Spectral sample taking: $1.2-10 \mathrm{~nm}$;

- Ground resolution: $1.5 \mathrm{~m}$ (with plane flight altitude)

Before mosaicing of the images parametrical correction and radiometric normalization between the bands were applied (Figure 1).

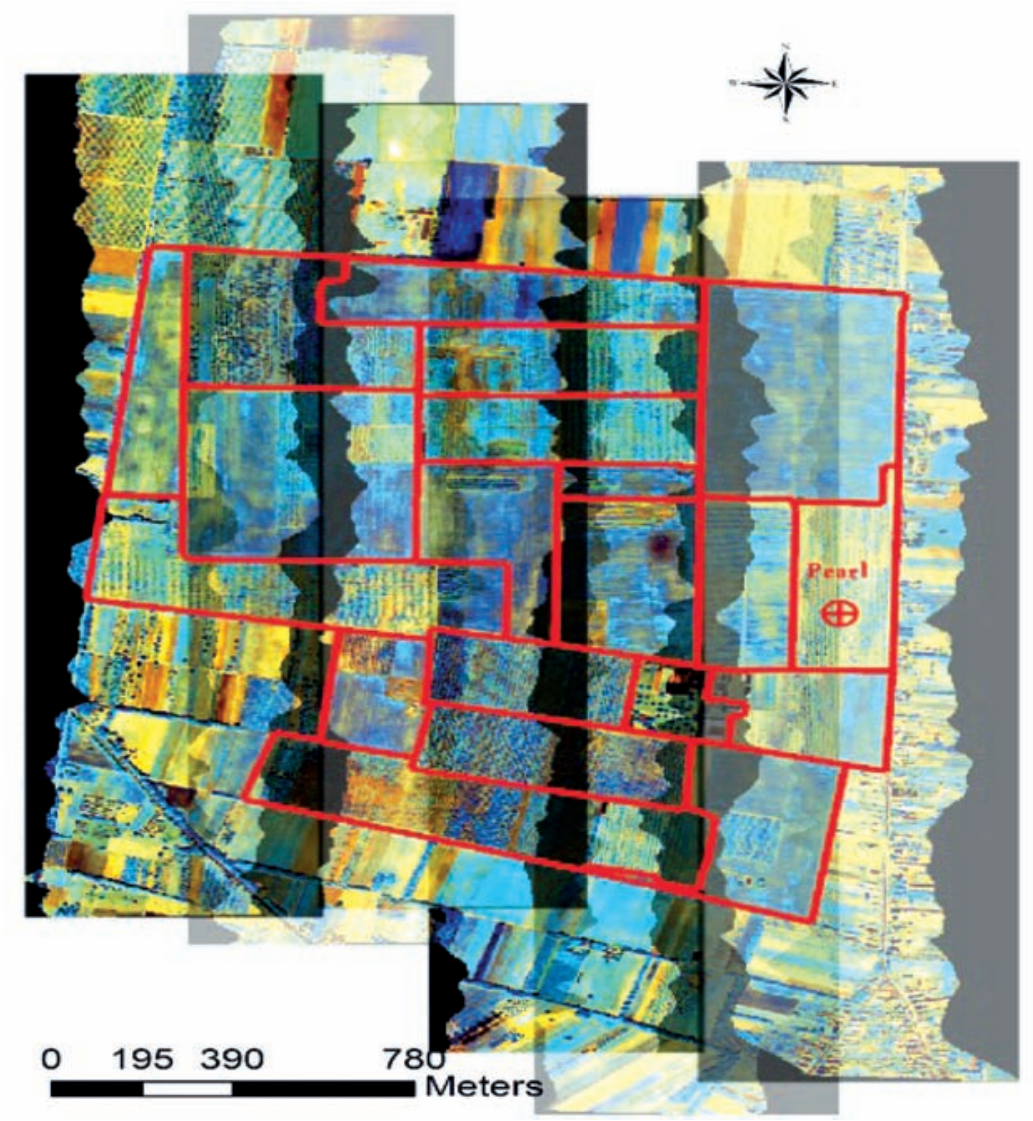

Figure 1. Georectified flight strips of the hyperspectral images and the Újfehértó Research Station (Red border lines represent the borders of the parcels; Red cross shows the situation of the pear orchard)

The digital elevation model of the study area was determined by the Spatial Analyst module of ArcMap 9.2 software. Digital elevation model with $1 \mathrm{~m}$ vertical and $0.2 \mathrm{~m}$ horizontal RMS was produced. However, the elevation models generated from contour lines or elevation points represents only the soil surface, while these cannot illustrate objects on the surface. Consequently, the value of the soil 
surface can be calculated with the radiation process. While the extent of the foliage can be modified the radiation data, it was determined with the help of the hyperspectral image. NDVI (Normalized Difference Vegetation Index) were calculated, which signs the foliage. A GIS model was created to process several classifications, logical or mathematical operations in ArcGIS 9.2 software environment too. With the help of logical (Boolean) operations we separated the relative height values to certain field features into different layers (Figure 2.).

In course of the establishment of the GIS logical model we determined the types of the accessible data and the forms of utilization in the geoinformatics system (Figure 3).

The fruit tree was the smallest unique entity, which has individually pollable attributes (name of species, planting date, height, condition etc.) It was also important to ensure the uploading of the phenological data such us blossoming, ripening time, and yields. To grant the agricultural subsidy it had to record the cultivation data of the area too. Based on field work and hyperspectral image unique data of all pear trees were registered in the genetic collection for agro-ecological environment evaluation and digital nutrition map was created. The pictures of trees and fruits were geotagged to air photo based on coordinates with Hyperlink option.

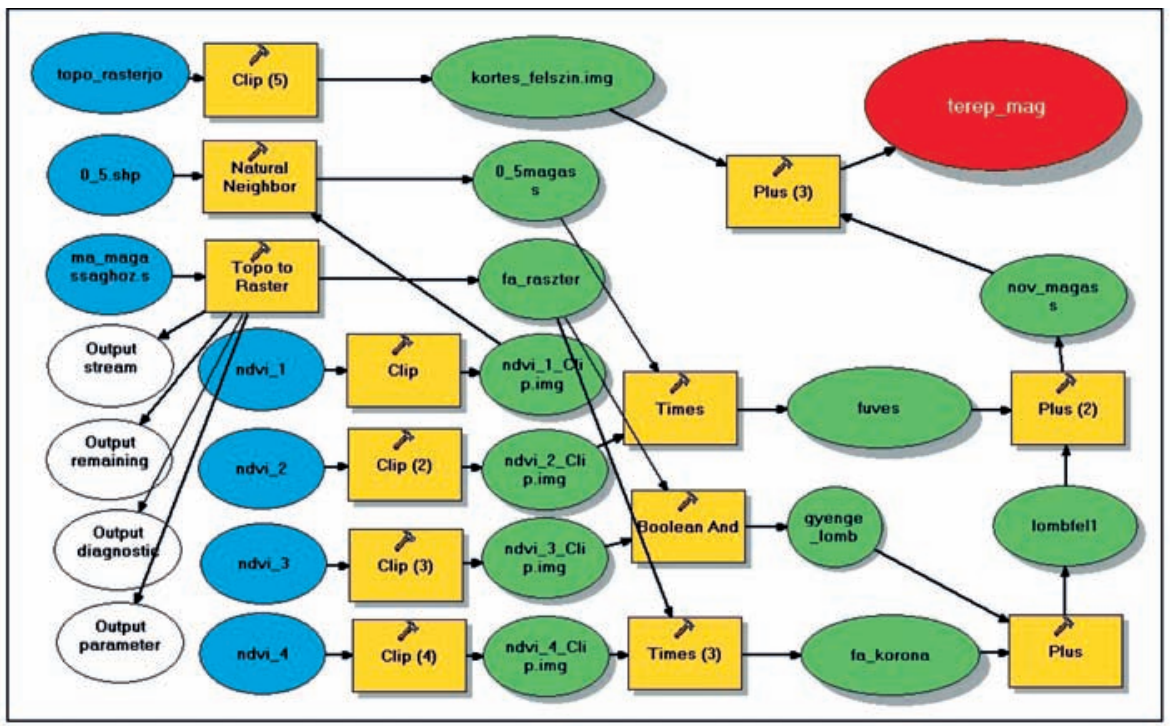

Figure 2. Marco model of the digital surfece model

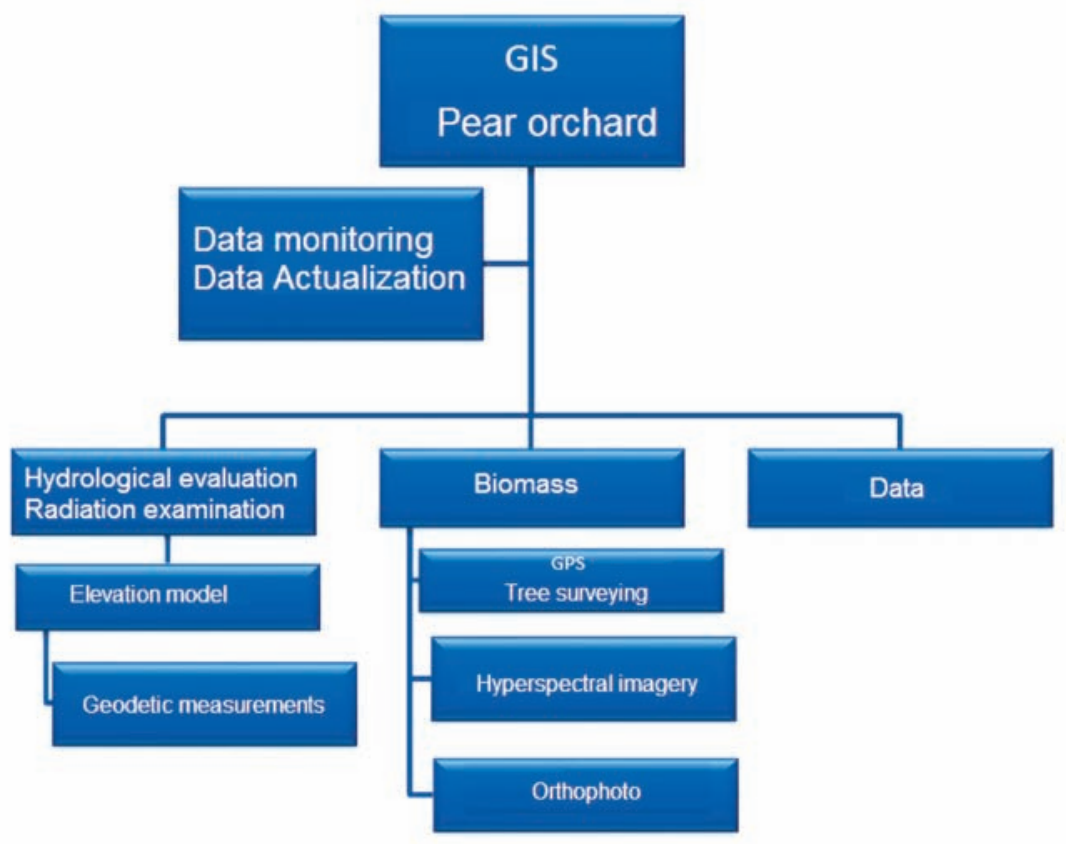

Figure 3. Conceptual data model of pear orchard

\section{Results and discussion}

All feature of the gene-collection can be identified and actualized (Figure 4). Attributes of the trees contain

- species, highly selected breeds,

- number of the row and stem,

- high of trees,

- date of plantation,

- data of origin,

- number of pictures,

- gene-cod,

- WGS and EOV coordinates (x, y) data.

Chlorophyll absorbs markedly spectral range between $450-670 \mathrm{~nm}$. The reflectance value of the vegetation without any stress is high at NIR intervals, but low at red wavelength interval. The chlorophyll content is one of the indicators of the state of health. NDVI index was calculated from the hyperspectral image. The Pearson correlation between chlorophyll and Normalized Vegetation Index (NDVI) was 0.8 , between chlorophyll and Simple Ratio Index (SRI) was 0.54 , between chlorophyll and Red Edge Position (REP) was -0.76 . The segmentation of the NDVI image was based on the GIS database of field measurements. After vectorising the obtained segments, those pear species having different biomass weight were selected. Pixels covered by canopies of these trees, could be spectrally clear and unmixed. Although the results show, that real endmember pixels can only be found at trees having several canopy level and at least $1 \mathrm{~m}$ canopy diameter. Because of the replacement of necrotized 


\begin{tabular}{|c|c|c|}
\hline \multicolumn{2}{|l|}{ Identify } & $x$ \\
\hline Identify from: & $n: \quad\langle$ Top-most layer> & $\nabla$ \\
\hline \multicolumn{3}{|l|}{ E-korte_fa } \\
\hline \multirow{2}{*}{\multicolumn{3}{|c|}{$\begin{array}{c}\text { Körte } \\
\text { Körte }\end{array}$}} \\
\hline & & \\
\hline \multicolumn{3}{|c|}{$\overline{ }$} \\
\hline Location: & 846638.534279123 .662 Meters & $\bar{x}$ \\
\hline Field & \multicolumn{2}{|l|}{ Value } \\
\hline OBJECTID & \multicolumn{2}{|l|}{1474} \\
\hline Shape & \multicolumn{2}{|l|}{ Point } \\
\hline Id & \multicolumn{2}{|l|}{1474} \\
\hline azonosito & \multicolumn{2}{|l|}{ T2AK8-A-07 } \\
\hline parcella & \multicolumn{2}{|l|}{$0111 b$} \\
\hline$x$ & \multicolumn{2}{|l|}{846637,664700001} \\
\hline y & \multicolumn{2}{|l|}{279122,330800001} \\
\hline $\mathrm{Faj}$ & \multicolumn{2}{|l|}{ Körte } \\
\hline Fajta & \multicolumn{2}{|l|}{ Nagy dorogi nyári körte 1} \\
\hline Sor & \multicolumn{2}{|l|}{17} \\
\hline Tö & \multicolumn{2}{|l|}{27} \\
\hline Állapot & \multicolumn{2}{|l|}{ új } \\
\hline Telepités & \multicolumn{2}{|l|}{0} \\
\hline magaasag & \multicolumn{2}{|l|}{1.5} \\
\hline \multicolumn{3}{|l|}{ fa_kep } \\
\hline \multicolumn{3}{|l|}{ gyum_kep } \\
\hline genmeg & \multicolumn{2}{|l|}{ i } \\
\hline gen_kod & \multicolumn{2}{|l|}{ UJKÖ00269 } \\
\hline szarmazas & \multicolumn{2}{|l|}{ Hajdúdorog } \\
\hline \multicolumn{3}{|c|}{ Identified 2 features } \\
\hline
\end{tabular}

Figure 4. Identify window of database

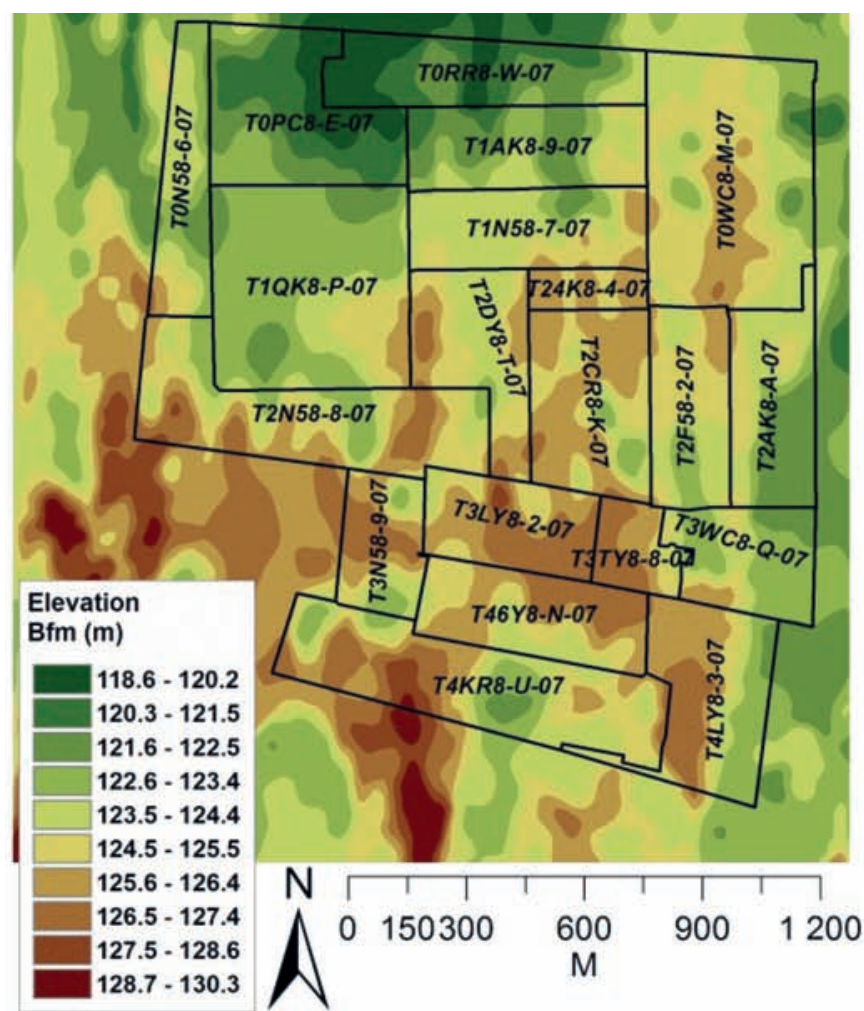

trees the spectral properties of grass zone between rows can provide spectrally mixed values (as a $2^{\text {nd }}$ type errors of commission) due to the possible underdevelopment of trees. On the other hand, the spectral properties of neighbouring trees can be mixed due to the overdeveloped tree canopy having more than $4 \mathrm{~m}$ diameter, which larger than the spacing in the row. Generally these errors of commission ( $1^{\text {st }}$ type) had minor role. The resulted, classified spectral data could be applied as a spectral library, which are suitable for the detailed examination of plant physiology and spectral data.

The digital elevation model (DEM) is a most part of the geoinformatical system, because of it is the basis of the ecological examinations. The measuring of the drought and water catchments is also very important.

However, the elevation models generated from contour lines or elevation points could be applied to evaluate agroecological potential of fruit orchards to some extent especially plain area with small elevation differences. These soil surface elevation maps do not contain the artificial objects (Dubayah és Rich, 1995) such as fruit trees. Soil surface category means the actual surface elevation which was determined by digital elevation model. Every other category has height data measured in field. The real height data of tree-top and the foliage were used in the course of interpolation as regards dense and poor vegetation categories. In this case we used the 1:10000 scale of DEM of investigation area at Újfehértó prepared by Inverse Distance Weighted method. In this area there is a $12 \mathrm{~m}$ relative relief, consequently the DEM shows that the area has very significant micro-relief differences (Figure 5). The sanddunes caused the forming of varied spatial pattern of the local

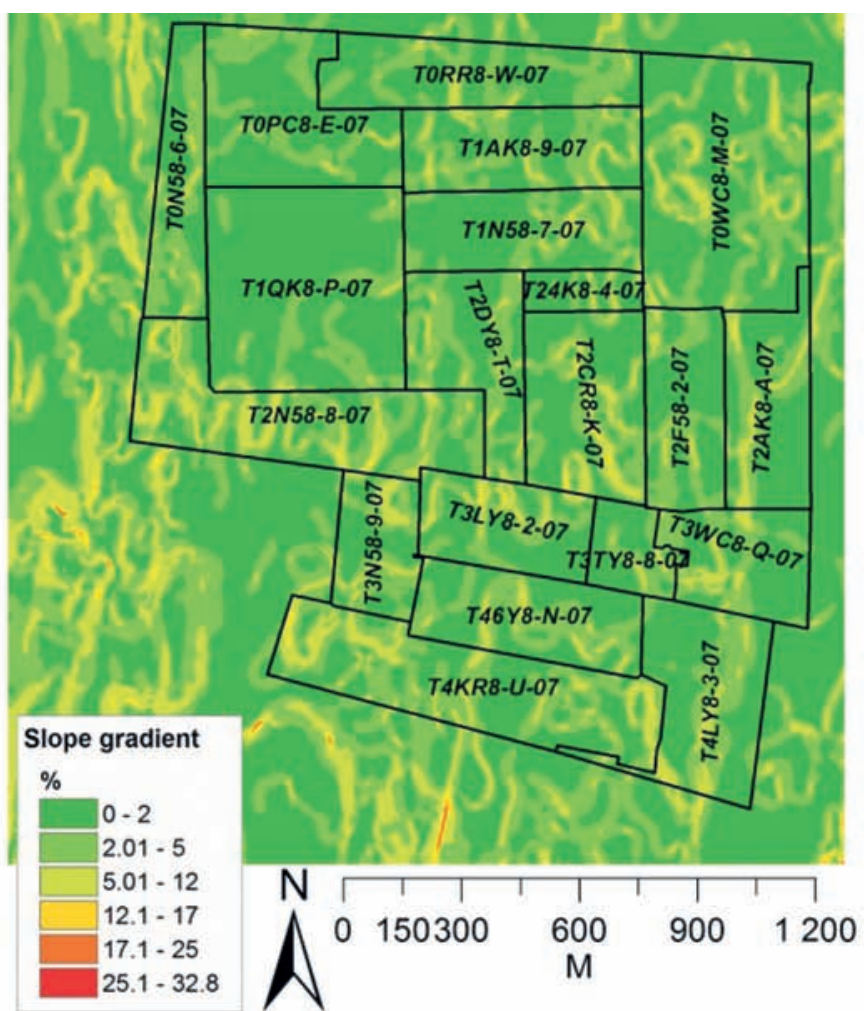

Figure 5. Digital elevation model and the slope gradient map (\%) of investigation area 

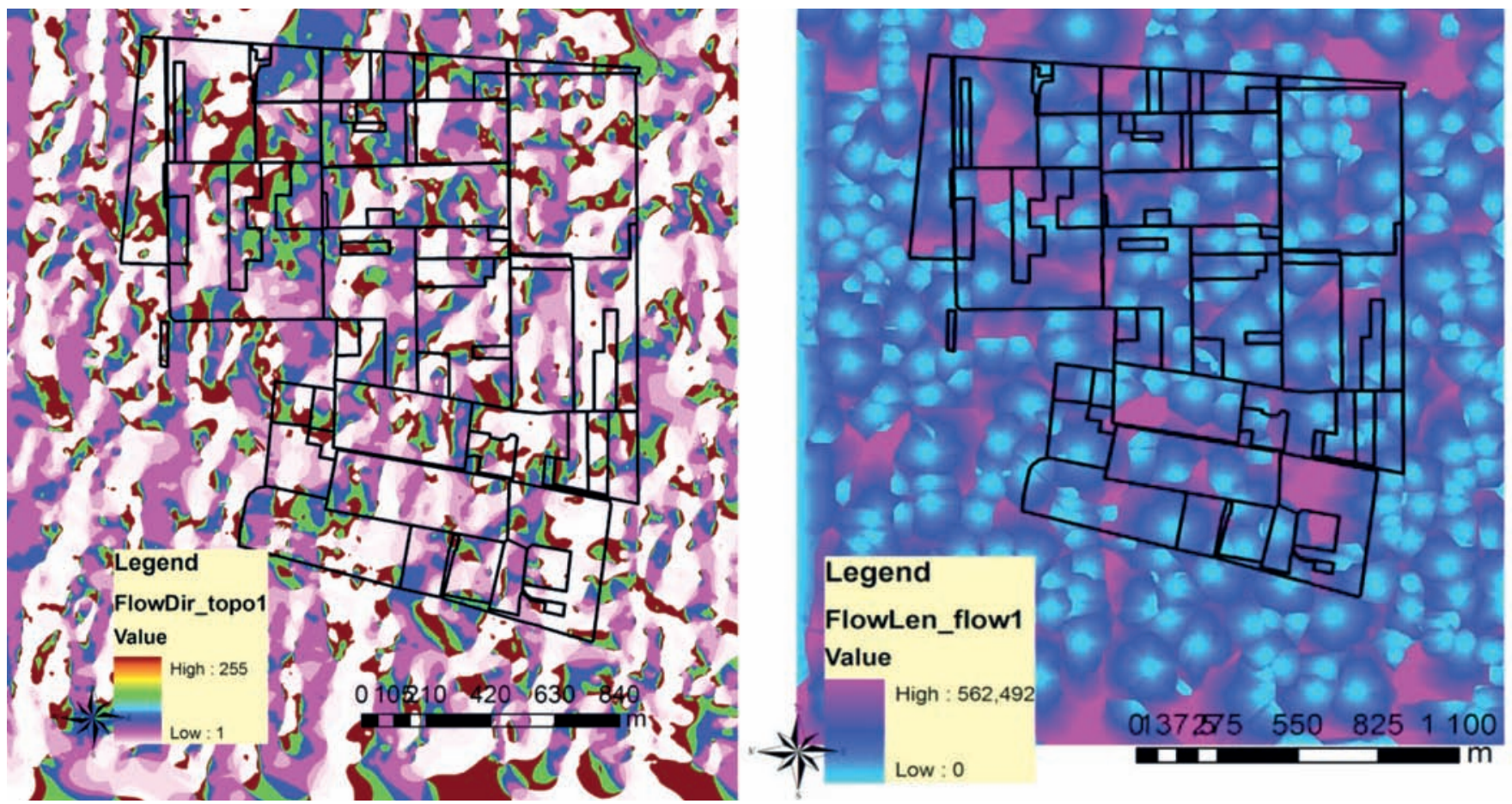

Figure 6. The flow direction and length in the investigation area at Újfehértó

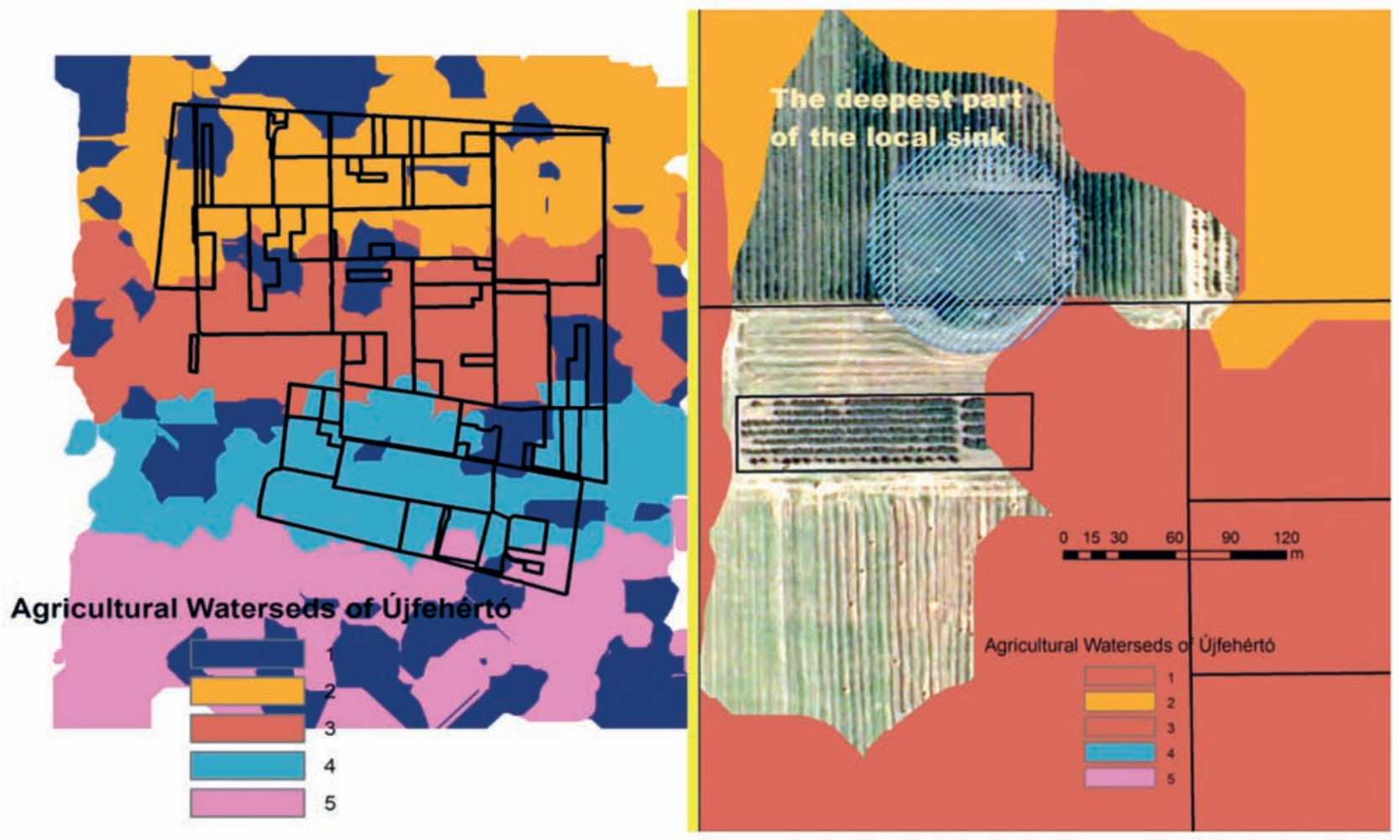

Figure 7. Small water catchments in the investigation area; The deepest sink of the parcels

drainage divides and water catchments in a relatively small. According to relief data it could not be prospective $18 \%$ of local gradient, which is characteristic of hilly country.

The digital map technique can be suitable for determining of the smallest differences in water catchments. The longest flow length is $562,4 \mathrm{~m}$ in this area. These include several local sink without an outlet keeping up anaerobe conditions (Tamás et al. 2011). These are located separately along four other zones in North-South direction (Figure 6).

Based on our experiences we conclude that better information could be gained using remote sensing and measures such as leaf-area index. On the basis of the results 
of NDVI examination, we determined four different categories as follows:
1. No vegetation- soil surface:
0,889 ha
2. Weed:
0,674 ha
3. Poor vegetation:
0,925 ha
4. Dense vegetation:
0,464 ha

It must be noted that the second and third categories also contain the new plantations ( $2-5$ years old) because of small foliage in the north part of the plantation.

Soil surface category means the actual surface elevation which was determined by digital elevation model. Every other category has height data measured in field. The real height data of tree-top and the foliage were used in the course of interpolation as regards dense and poor vegetation categories. The results show, that real endmember pixels can only be found at trees having several canopy level and at least $1 \mathrm{~m}$ canopy diameter. Because of the replacement of necrotized trees the spectral properties of grass zone between rows can provide spectrally mixed values due to the possible underdevelopments of trees. On the other hand, the spectral properties of neighbouring trees can be mixed due to the overdeveloped tree canopy having more than $4 \mathrm{~m}$ diameter, which larger than the spacing in the row. The resulted, classified spectral data could also be applied as a spectral library, which are suitable for the detailed examination of plant physiology and spectral data (Figure 8).

It can be mentioned, that the second and third categories contain the new plantations ( $2-5$ years old), because of small foliage. While the youngest trees have not extent that influences the radiation, we joint $1 \mathrm{~m}$ height for these pixels uniformly. To the pixels of weed vegetation $0.5 \mathrm{~m}$ height were assigned.

To the values of the digital elevation model was added the data generated by interpolation of foliage height in the case of the pixels of the dense and poor vegetation categories. While the interpolation operations assign height values to the pixels that represent grass vegetation or soil surface, logical operations had to be processed to separate. Finally after uniting the layers with mathematical methods, the terrain model relating to the orchard was ready this already illustrates the orchard's "surface raggedness" statuesquely, and serves as a base for further researches.

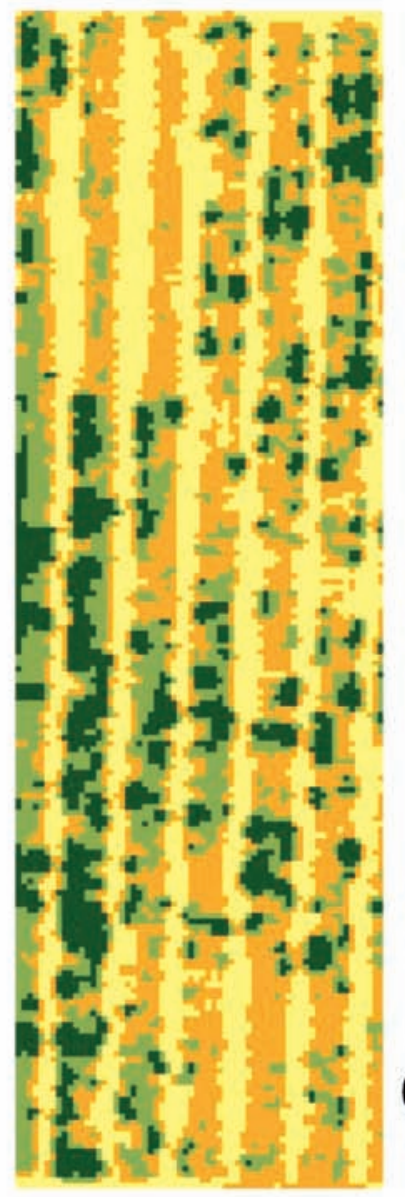

A

\section{Legend \\ NDVI_value}
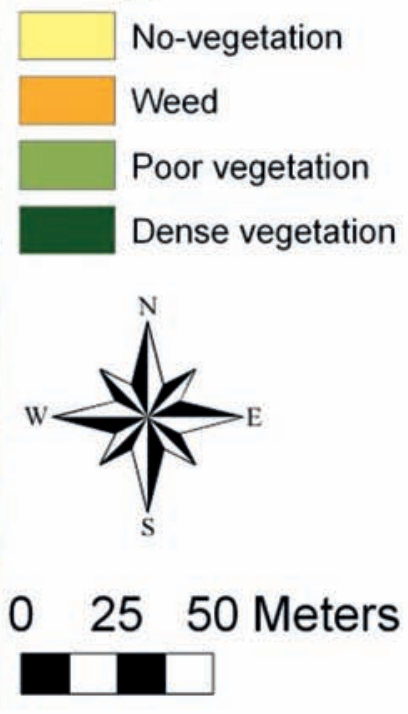

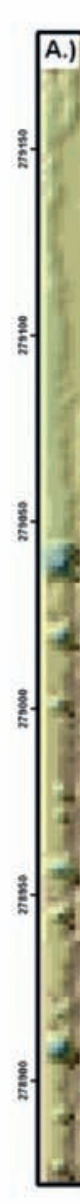

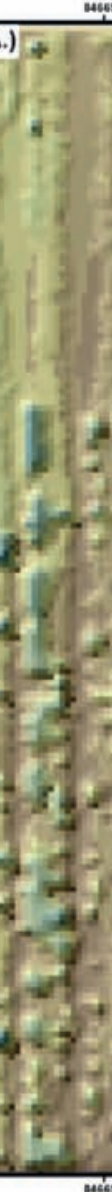

Messo

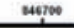

Terrain modell

Elevation

$121-122$

$122-123$

$123-124$

$\square 124-125$

$125-126$

$126-127$

$127-128$

$\begin{array}{r}127-128 \\ 128-129 \\ \hline\end{array}$

\section{I}

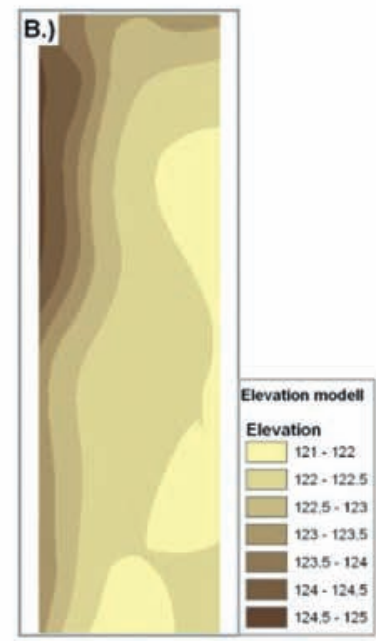

B

Figure 8. A.)NDVI values of the pear orchard; B.) Complete terrain model 


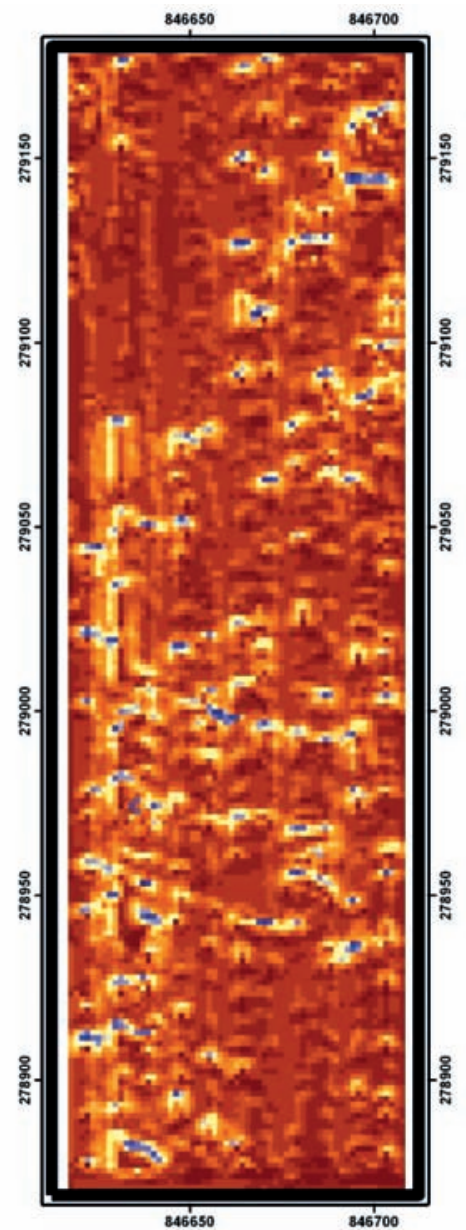

Figure 9. Direct radiation values in June

The different radiation maps of the study area were prepared in every phenological phase (e.g. April, June, August, September) and we calculated the maximal direct radiation values in the matter of clear sky (Nagy et al. 2011). The spatial resolution of the map is $1,5 \mathrm{~m}$ and the values represent in Watt $\mathrm{h} / \mathrm{m}^{2}$ (Figure 9).
While the geoinformatical model contains origin data of pear species, we prepared map of origin in WGS84 projected coordinate system (Figure 10).

\section{Conclusion}

The high spatial resolution digital geoinformatical system of pear orchard is suitable for decision support tasks and provides opportunity for actualization, data input, evaluation to establish monitoring system. This normalized GIS system is adaptable for other sites.

In our investigations, the airborne imaging system was used in fruit researches to develop a new GIS based recording system of fruit plantations and study the relationships between remotely-sensed indices and ground control measures of fruit trees. Based on our experiences we conclude that better information could be gained using hyperspectral image. There is scope to research the combined approach of simulation models with geographical information systems and digital terrain (elevation) models, and remote sensing. The terrain model generated and applied by our team demonstrates fine surface texture and the landmarks in the orchard, so it is suitable for further examination.

The climatic stress has an effect on vegetation, as well as other living creature. Species, grown in the concerned landscape had enhanced tolerance for harmful effects and water stress, thus it is especially important to prevent these genetic properties for further generations. The spectral library of the pear genetic collection in Újfehértó and the integrated GIS research database provide new opportunity to researchers and breeders in vegetation analysis.

\section{Acknowledgement}

This study is funded by TECH_08-A3/2-2008-0373 and TECH_08-A4/2-2008-0138 projects.

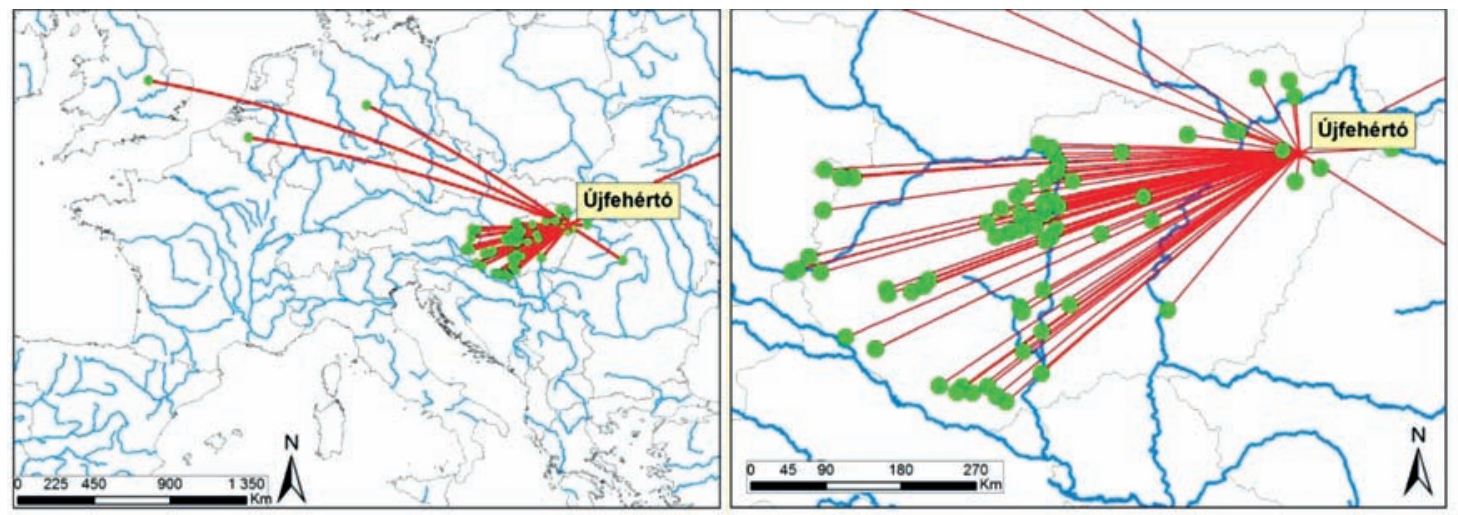

Figure 10. Map of origin 


\section{References}

Allen, R. G., Pereira, L. S., Raes, D., Smith, M. (1998): Crop evapotranspiration: Guidelines for computing crop requirements. Irrigation and Drainage. Paper No. 56, FAO, Rome, Italy, 300.

Champagne, C., Pattey, E., Bannari, A., Stratchan, I. B. (2001): Mapping Crop Water Status: Issues of Scale in the Detection of Crop Water Stress Using Hyperspectral Indices. In: Proceedings of the $8^{\text {th }}$ International Symposium on Physical Measurements and Signatures in Remote Sensing, Aussois, France, 79-84.

Dubayah, R., Rich, P. M. (1995): Topographic solar radiation models for GIS. Int. J. Geographical Systems 9, (4): 405-419.

Holzwarth, S., Müller, R., Simon, C. (2005): Determination and monitoring of boresight misalignment angles during the hymap campaigns HYEUROPE 2003 and HYEUROPE 2004. [In: Zagajewski, B., Sobczak, M., Wrzesien, M. (eds.): Proceedings of 4th EARSeL Workshop on Imaging Spectroscopy. New quality in environmental studies]. EARSeL and Warsaw University, Warsaw, 119-128.

Kocsisné Molnár, G. (2006): Körtefajták értékelése a Georgikon Mezőgazdasátudományi Kar körte génbankjában. PhD. értekezés. Pannon Egyetem
Láng, I. (2007): Getting prepared to combat climatic changes in Hungary. Changes - Impacts - Responses the project VAHAVA. Budapest

Lockie, S., Carpenter, D. (2009): Agriculture, biodiversity, and markets: livelihoods and agroecology in comparative perspective. Earthscan Ltd., London, UK, 336.

Milics, G., Virág, I., Farouk, M., Burai, P., Lénárt, Cs. (2010): Airborne hyperspectral imaging for data collection for resilient agro-ecosystems. Növényterm. 59. 6: 593-597.

Nagy, A., Fórián, T., Tamás, J. (2011): Applied spatial analyst tools in orchard special regard to agro-ecology International Journal of Horticultural Science, 17: 68-73.

Tamás, J., Fórián, T., Nagy, A., Soltész, M., Nyéki, J., Szabó, Z. (2011): Digitális domborzati modellek létrehozása és alkalmazhatósága a gyümölcsösök agroökológiai potenciáljának értékelésére. AGRO 21. MTA. Budapest, 106-114.

Tamás, J., Szabó, Z. (2010): Hyperspectral evaluation of the pear trees on the basis of genetic collection of different speies. [In Wagner, W., Székely, B. (eds.): International Society for Photogrammetry and Remote Sensing (ISPRS)] TC VII. Vienna, Austria, July 5-7, 2010. IAPRS, Vol. 38 (7B): 563-567. 